\title{
Corporate Sustaining Members, 1989-90
}

A \& L Lafrenière Lumber Ltd.

Apollo Forest Products Ltd.

Boise Cascade Canada Ltd.

Bowater Mersey Paper Company Limited

Chapleau Forest Products Limited

Crestbrook Forest Industries Ltd.

Dubreuil Brothers Ltd.

Équipements Denis Inc.

Forestry Canada, Forêts Canada

Jiffy Products (N.B.) Ltd.

Les Produits Forestiers Daishowa Ltee.

Lignum Ltd.

Minas Basin Pulp and Power Company Ltd.

Noranda Forest Inc.
Quebec \& Ontario Paper Co. Ltd.

Ridgetown College of Agricultural

Technology

Skeena Cellulose Inc.

St. Marys Paper Inc.

Stora Forest Industries Ltd.

Tembec Inc.

Town of Hinton

United Brotherhood of Carpenters, Local Union 2564, Grand Falls, Nfld.

University of Toronto, Faculty of Forestry

Wajax Industries Ltd.

Weldwood of Canada Ltd.

West Fraser Mills Ltd.

Noranda Forest Sales Inc.

The Contribution of our Corporate Sustaining Members is Gratefully Acknowledged 